\title{
Preliminary studies on the gene map of cattle
}

\author{
LV Monteagudo, MT Tejedor, MV Arruga
}

Facultad de Veterinaria, Universidad de Zaragoza, Laboratorio de Citogenética, Departamento de Anatomia, Embriologia y Genética, C/Miguel Servet, 177, 50013 Zaragoza, Spain

(Proceedings of the 9th European Colloquium on Cytogenetics of Domestic Animals; Toulouse-Auzeville, 10-13 July 1990)

gene map / cattle

\section{INTRODUCTION}

Gene mapping has become one of the most interesting fields in genetics research. However, data available on animal gene mapping are still very few, as compared with present knowledge of the human gene map. During the last two decades, somatic cell hybridization has proven to be one of the most useful tools for gene mapping studies both in the human and in animal species (Pontecorvo, 1975). In this report, we present our preliminary results in cattle gene mapping, obtained using this methodology.

\section{MATERIALS AND METHODS}

\section{Somatic cell hybridization}

Somatic cell hybridization was performed as described by Pontecorvo (1975). The line wg3hcl2 (a Chinese hamster cell line negative for hypoxanthine phosphoribosyltransferase (HPRT); Echard et al, 1984) and fibroblasts obtained from one cow were used for this purpose. Hypoxanthine-aminopterine-thymidine (HAT) culture medium was used to prevent growth of $\mathrm{HPRT}^{-}$cells. Ouabain was added to the medium at a final concentration of $10^{-7} \mathrm{M}$, to prevent growth of the unfused cattle fibroblasts.

\section{Karyotype analysis}

Karyotyping and cellular extract analysis for isozyme characterization were carried out at the same culture passage; colcemid (GIBCO) was added 3 or $31 / 2 \mathrm{~h}$ before harvesting, at a final concentration of $0.05 \mu \mathrm{g} / \mathrm{ml}$. Cells were then removed from the culture flask, underwent a 20 min hypotonic treatment with $0.075 \mathrm{M} \mathrm{KCl}$ and were fixed twice in methanol-acetic acid $(3: 1)$, before slides were prepared. 
Isozyme characterization

Cells were removed from the culture flask by trypsinization. As soon as cells started to detach, they were diluted in Hanks' balanced salt solution (HBSS). Sometimes, $10 \%$ fetal calf serum was added to HBSS to prevent trypsin degradation of enzymes. After centrifugation, cells were diluted in Shaws' buffer and subjected to three freezing-thawing cycles before being sonicated. Finally, samples were centrifuged and the supernatants (containing the enzymes) were stored in liquid nitrogen until analyzed. Electrophoresis of the samples, followed by specific staining was used to characterize the cattle isozymes expressed in the hybrid clones. The references for tank buffers and staining procedures are as follows: AK: adenylate kinase (Heuertz, 1981); PGD: phosphogluconate dehydrogenase (Heuertz, 1981); FH: fumarate hydratase (Harris and Hopkinson, 1976); MANA: $\alpha$-mannosidase (Harris and Hopkinson, 1976); ACP: acid phosphatase: buffers according to Benne (1990, personal communication) and staining procedure described by Harris and Hopkinson (1976); LDHA and LDHB: lactate dehydrogenase A and B (Van Someren et al, 1974); PGM1, PGM2 and PGM3: phosphoglucomutase (Heuertz, 1981); NP: nucleoside phosphorylase: buffers used by Womack and Moll (1986) and staining procedure described by Ansay and Hanset (1972); PEPC: peptidase C: buffers and staining method of Van Someren et al (1974).

\section{RESULTS AND DISCUSSION}

We have now obtained a panel of 31 hybrid clones. So far, 14 clones have been analyzed for the following genes: AK, PGD, FH, MANA, ACP, LDHA and B, PGM1, 2 and 3, NP and PEPC (table I).

Table I. Cattle enzymes detected in the hybrid clones (hamster $\times$ cattle).

\begin{tabular}{|c|c|c|c|c|c|c|c|c|c|c|c|c|}
\hline \multirow[t]{2}{*}{ Clones } & \multicolumn{12}{|c|}{ Enzymes } \\
\hline & $A K$ & $P G D$ & $F H$ & $M A N A$ & $A C P$ & $\angle D H A$ & $L D H B$ & $P G M 1$ & PGM2 & $P G M 3$ & $N P$ & $P E P C$ \\
\hline 4 & - & - & & - & - & - & + & & & & & \\
\hline $3-22$ & - & - & - & - & - & + & - & & & & & \\
\hline $3-15$ & & - & - & - & - & - & - & - & - & + & + & \\
\hline $2-1$ & & - & - & - & - & - & - & - & & & - & \\
\hline $2-8$ & - & - & + & & - & - & - & - & - & - & - & \\
\hline $5-20$ & - & - & - & - & & + & + & - & - & + & & \\
\hline $2-2$ & - & - & - & + & - & - & - & - & - & - & - & + \\
\hline $3-11$ & - & + & - & + & - & - & - & - & - & - & & \\
\hline $2-12$ & & - & - & + & - & - & - & - & - & - & - & - \\
\hline $7-7$ & & - & - & & + & + & + & - & + & + & - & \\
\hline $7-1$ & & - & - & & + & + & + & - & + & + & - & \\
\hline $5-6$ & & + & + & & + & + & + & + & + & + & - & \\
\hline FUS & - & - & - & & & - & - & - & - & - & & - \\
\hline $3-17$ & - & - & - & + & + & - & - & - & - & - & & - \\
\hline
\end{tabular}


Previously, PGD was found to belong to the bovine U1 syntenic group, while PGM1 was located in the U6 syntenic group (Echard et al, 1982; Heuertz and Hors-Cayla, 1981; Womack and Moll, 1986; Womack, 1990). FH and PEPC were not previously studied (fig 1 shows the electrophoretic enzyme pattern obtained for $\mathrm{FH})$. Our data suggest that the human syntenic group including FH, PGD, PGM1 and PEPC (Van Someren et al, 1974) is not conserved in cattle. PGD, PGM1 and $\mathrm{FH}$ cannot be considered as being syntenic in light of the preliminary results shown in table I.

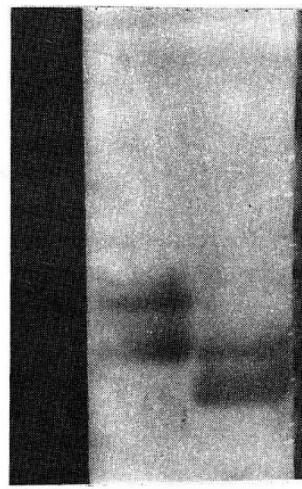

12

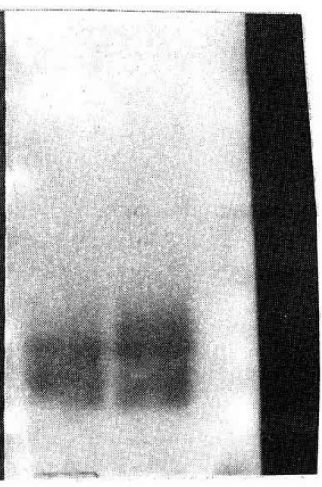

34
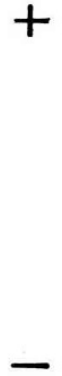

Fig 1. Cellulose acetate zymogram of FH: lane; 1 : cattle; 2 : hamster; 3 : negative hybrid for cattle $\mathrm{FH}$; 4 : positive hybrid for cattle $\mathrm{FH}$.

\section{REFERENCES}

Ansay M, Hanset R (1972) Purine nucleoside phosphorylase (NP) of bovine erythrocytes: genetic control of electrophoretic variants. Anim Blood Groups Biochem Genet 3, 219-227 Echard G, Gellin J, Benne F, Gillois M (1982) Progress in gene mapping of rabbits, cattle and pigs using somatic cell hybridization. In: Proc 5th European Colloquium on Cytogenetics in Domestic Animals (Milan) (Succi G, ed), 237-252

Echard G, Gellin J, Gillois M (1984). Localisation des gènes MPI, PKM2, NP sur le chromosome 3 du porc (Sus scrofa L) et analyse cytogénétique d'une lignée de hamster chinois issue de la DON (wg3h). Génét Sél Evol 16, 261-270

Harris H, Hopkinson DA (1976) Handbook of Enzyme Electrophoresis in Human Genetics. North Holland, Amsterdam

Heuertz S (1981) Carte génétique des bovins par les techniques d'hybridation cellulaire. Doctoral thesis. Université de Paris-Sud Orsay, Paris XI

Heuertz S, Hors-Cayla MC (1981) Cattle gene mapping by somatic cell hybridization: study of 17 enzyme markers. Cytogenet Cell Genet 30, 137-145

Pontecorvo G (1975) Production of mammalian somatic cell hybrids by means of polyethylene glycol treatment. Somatic Cell Genet 1, 397-400

Van Someren H, Van Henegouwen HB, Westerveld A, Bootsma D (1974) Synteny of the human loci for fumarate hydratase and UDPG pyrophosphorylase with chromosome 1 markers in somatic cell hybrids. Cytogenet Cell Genet 13, 551-557

Womack JE (1990) Gene map of the cow (Bos taurus). In: Genetic Maps. vol 5 (O'Brien SJ, ed) Cold Spring Harbor Laboratory, Cold Spring Harbor, NY, 4121-4125

Womack JE, Moll YD (1986) Gene map of the cow: conservation of linkage with mouse and man. $J$ Hered $77,2-7$ 